\title{
Micromagnetic Simulation of Magnetization States Recorded by Perpendicular Magnetic Duplication
}

T. Komine, A. Izumi, T. Murata, and R. Sugita

Dept. of Media and Telecomm. Eng., Ibaraki University,4-12-1 Nakanarusawa-cho, Hitachi, Ibaraki 316-8511, Japan

We demonstrated the micromagnetic simulation of magnetic duplication for perpendicular magnetic recording (PMR) media The magnetization distributions of the PMR media duplicated by edge printing (EP) and bit printing (BP) were investigated. The dependence of duplication characteristics on the duplication field was also estimated. An AC erase state in the off-track region appeared for a strong duplication field in EP. The dependence of the duplication characteristics on the duplication field we found in this study is in agreement with that calculated by macroscopic-magnetization analysis in a previous report. Although the intergrain exchange constant has almost not influence on the duplication characteristics in EP, the duplication characteristics in BP are improved as the intergrain exchange constant increases.

Key words: magnetic duplication, perpendicular recording media, micromagnetic simulation

\section{垂直磁気転写された磁化状態のマイクロマグネティックシミュレーション}

小峰啓史 · 和泉昭彦 ·村田剛史 ·杉田龍二

茨城大学工学部, 茨城県日立市中成沢町 4-12-1 (广 316-8511)

\section{1 はじめに}

近年の垂直磁気記録の実用化 , 高記録密度化に伴い , 信号の 位置情報であるサーボ信号の書き込み時間の増大が問題となっ ている.垂直磁気転写法は, 垂直磁気記録方式を用いたハード ディスクにサーボ信号を高速かつ安価に書き込む方法として注 目されている ${ }^{1,2)}$. 垂直磁気転写における磁化状態解析には， 従来，巨視的磁気特性が用いられていたが ${ }^{3)}$ ，現実のハード ディスクに対する詳細な転写特性を議論する場合，垂直磁化膜 の異方性分散，粒子間交換結合などの，スレーブ媒体の微視的 磁気特性が磁気転写に及ぼす影響を知る必要がある．本研究で は, スレーブ媒体の微視的な磁化状態を解析するため, マイク ロマグネティックシミュレーションを用いて, 転写条件及びス レーブ媒体の粒子間交換結合が垂直磁気転写特性に及ぼす影響 を調べた

\section{2 計算方法}

エッジ転写においては， AC 消磁状態のスレーブ媒体にマス ター媒体を接触させ，媒体膜面内方向に転写磁場を印加する。 すると , パターニングされたマスター磁性膜エッジ部で強い垂 直磁場成分が現れ，これに対応するマスター磁性膜エッジ部 でスレーブ媒体が垂直方向に磁化される. ビット転写において は, はじめに , スレーブ媒体の垂直方向に初期磁場を印加して 一方向に初期磁化し，初期磁化したスレーブ媒体にマスター媒 体を接触させ, 初期磁化と反対向きに転写磁場を印加する . こ れにより，マスター磁性膜接触部では磁場が強くなるため初期 磁化が反転し，非接触部では磁場が弱くなり初期磁化が保存さ れる. 兴の結果，マスター媒体のパターンがスレーブ媒体に転 写される．本研究では，垂直転写された磁化状態を解析するた め, 転写磁場印加時の記録磁場分布を有限要素法により計算
し，弚の磁場分布を用いてスレーブ媒体の磁化状態をマイクロ マグネティックシミュレーションにより求めた .

3 次元有限要素法を用いてポアソン方程式を解き，Fig. 1 に 示す計算モデルの記録層部に発生する記録磁場を計算した . マ スター磁性膜パターン幅及び磁性膜間隔の等しいパターンが 無限に配置されているマスター媒体を想定した . マスター磁性 膜の寸法はトラック幅 $100 \mathrm{~nm}$, 磁性膜厚 $100 \mathrm{~nm}$, パターン幅 (ビット長)およびピッチを $100 \mathrm{~nm}$ とした．また，軟磁性裏打 層 (SUL) は膜厚 $200 \mathrm{~nm}$ として, 記録層に接しているとした マスター磁性膜及び SUL の磁気特性は, 飽和磁化 1900, 800 $\mathrm{emu} / \mathrm{cm}^{3}$ を乥れ午れ用い，飽和を考慮してヒステリシスを折 れ線で近似して，透磁率を关れ光れ 100 とした 。

次に計算された記録磁場分布を用いて，垂直磁化膜の磁化状 態をマイクロマグネティックシミュレーションにより求めた . 計算領域は Fig. 1 に示すように磁性膜パターンが $3 \times 3$ 個含 まれる領域を想定し，面内方向にはマスター磁性膜パターンが 周期的に配置されているとして，面内周期境界条件を課した。 SUL には記録層の鏡像が現れるものとして，鏡像が作る静磁 場を考慮した。

記録層は，飽和磁化 $500 \mathrm{emu} / \mathrm{cm}^{3}$ ，平均の一軸異方性磁場 $8 \mathrm{kOe}$, 異方性分散 $0.8 \mathrm{kOe}$ ，角度分散 $10^{\circ}$, 膜厚 $20 \mathrm{~nm} の$ 垂 直磁化膜を想定した．垂直磁化膜は，5 nm ×5 nm × $20 \mathrm{~nm} の$ 直方体単磁区粒子で構成されているとしてセルに分割し，粒 子間交換結合 $A$ を $1.0 \times 10^{-7} \mathrm{erg} / \mathrm{cm}$ として，基準値 $A_{0}$ とし た .これらの磁気特性は, 我々が以前に解析に用いたマクロな 磁気特性と概ね対応し，保磁力付近でのヒステリシスの傾き $\alpha\left(\equiv 4 \pi d M /\left.d H\right|_{H=H_{\mathrm{c}}}\right)$ は約 2.5 ，保磁力 $H_{\mathrm{c}}$ は約 $4 \mathrm{kOe}$ ，核生成 磁場 $H_{\mathrm{n}}$ は約-1.5 kOe であった .

面内方向に転写磁場 $H_{\mathrm{a}}$ を印加する転写方式であるエッジ転 写の場合，AC 消磁状態を初期状態として与えた . 有限要素法 


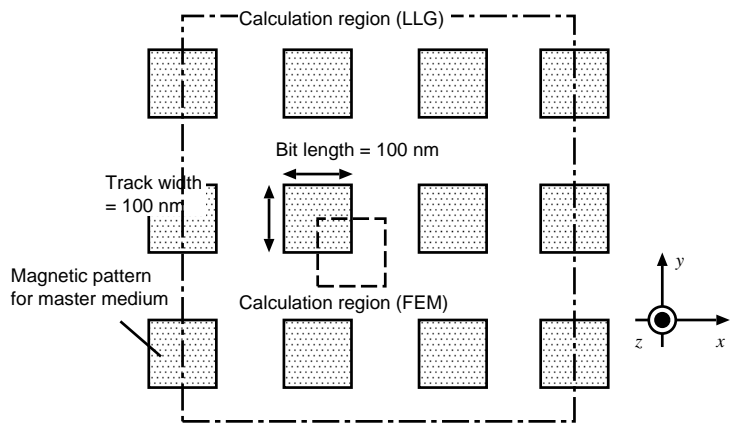

(a) Top view

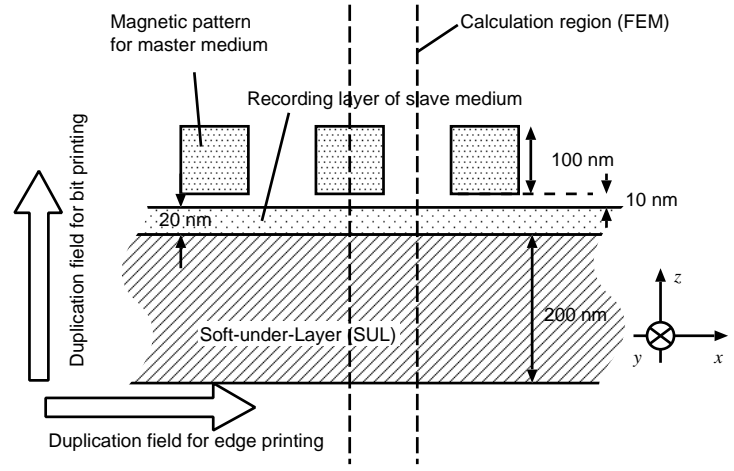

(b) Cross section

Fig. 1 Schematic illustration of calculation model for perpendicular magnetic duplication.

によって計算された転写磁場印加中の記録磁場分布を与えて， 転写中の磁化状態を計算した後, 磁場を取り去って転写後の磁 化状態を求めた，一方，膜面垂直方向に転写磁場を印加する転 写方式であるビット転写の場合では, 初めに垂直方向に初期磁 場を与えて DC 消磁状態を求めた，关の後，初期磁場とは逆向 きの転写磁場を印加している際の記録磁場分布を与えて磁化状 態を計算し，磁場を取り去って転写後の磁化状態を求めた。

転写磁場 $H_{\mathrm{a}}$ を变えて，エッジ転写及びビット転写された磁 化状態を比較，検討した．各々の転写特性を簡易に評価するた め,転写された記録層からの洩れ磁場を計算し，トラック幅 80 $\mathrm{nm}$ ，膜厚 $5 \mathrm{~nm}$ のフリー層を持つ GMR 素子が記録層とのス ペーシング $10 \mathrm{~nm}$ て配置されていると想定して , フリー層の ABS における平均磁場から再生出力を見積もつた．また，粒 子間交換結合 $A$ を变えて, 粒子間交換結合が転写状態に及ぼ す影響を調べた 。

\section{3 結果と考察}

3.1 ビット転写及びエッジ転写されたスレーブの磁化状態

Fig. 2 に転写磁場 $H_{\mathrm{a}}$ を変化させてエッジ転写した記録層の 磁化分布を示す． Fig. 2 を見ると，マスター磁性膜エッジ部に おいて，上向き，下向きの磁化か転写されていることがわか る.また, 転写磁場か弱いときには十分な転写が得られないも のの, 転写磁場強度か増すにつれて, 明瞭に磁化か転写されて いることがわかる .この傾向は, 記録層の磁気特性として, 巨 視的な磁気特性を仮定して解析した結果とも一致する．トラッ
クエッジ部に着目すると， $4 \mathrm{kOe}$ では転写された磁化が隣接卜 ラックでつながっているものの，転写磁場を強くするに従っ て AC 消磁状態に近づき，所望のトラック幅に近づくことが分 かる.

Fig. 3 に転写磁場 4 kOe を印加しているときのトラック中心 部における記録磁場分布，及び，磁場が容易軸となす角 $\theta$ の分 布を示す. Fig. 3 を見ると，磁性膜パターンエッジ部では，容 易軸方向に対して記録磁場が約 $40^{\circ}$ 程度傾いていることが分 かる. 各磁性粒子が Stoner-Wohlfarth モデルに従うとすれば， エッジ部分で容易に磁化反転が起こると推定される．

転写された磁化分布及び产の磁化過程を理解するため, 転写 磁場印加時及び転写後のオントラック , オフトラックにおける

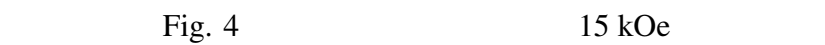
ントラック領域では，強い転写磁場を面内方向に印加すると， 転写磁場印加中の磁化はほとんど転写磁場の方向を向き，パ ターンエッジ部ではわずかに磁化の垂直成分を持つ . 転写磁場 を取り去ると，弚のわずかな垂直成分が起点となって，最終の 転写状態を決定する .一方，オフトラック部では記録磁場の垂 直成分がほとんど無いため, 転写磁場印加中では，面内方向に 磁化が向いている．弚の結果，垂直方向に磁化する起点が存在 しないため，AC 消磁状態か実現される.垂直磁気記録のサー ボ信号において , オフトラック領域の DC 消磁状態に起因する 再生波形の歪みか問題となっており，兴れを解消する試みか報 告されている ${ }^{4)}$. エッジ転写では, 転写を実行するだけでオフ トラック部での AC 消磁が自動的に行われており，サーボ信号 における再生波形丕みを同時に解消することが期待できる．

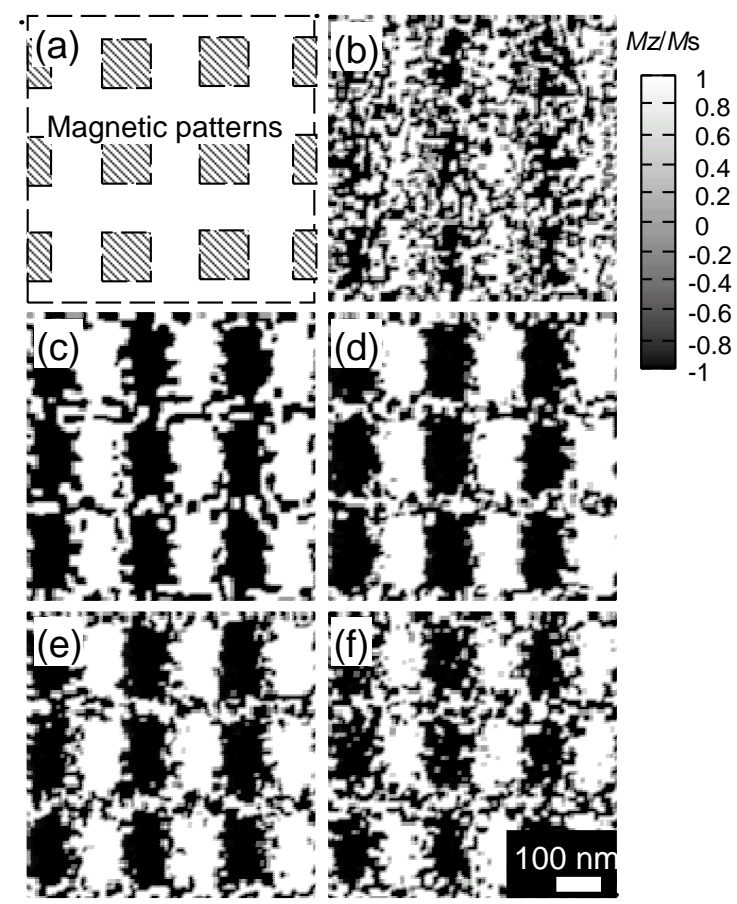

Fig. 2 (a) Alignment of master patterns in the calculation region. Magnetization distributions for the recording layer duplicated by edge printing with various duplication fields: (b) $2 \mathrm{kOe}$, (c) 4 $\mathrm{kOe}$, (d) $8 \mathrm{kOe}$, (e) $10 \mathrm{kOe}$, and (f) $15 \mathrm{kOe}$. 


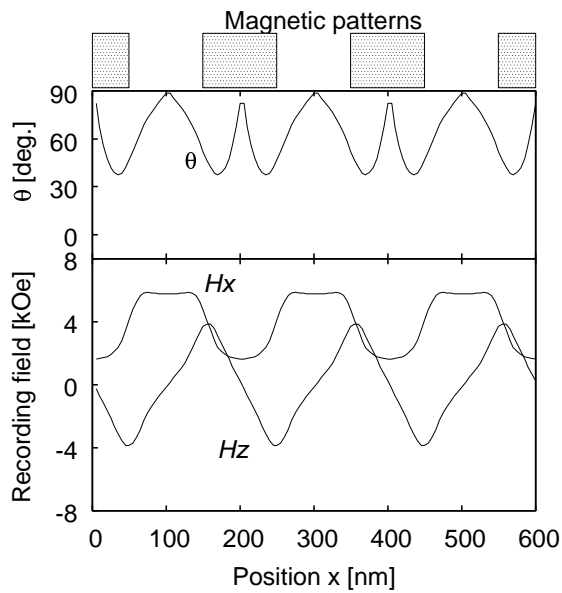

Fig. 3 Recording field distribution along the center of the track in EP (lower). The upper figure indicates angle $\theta$ with respect to the easy axis, which is defined as $\theta=\tan ^{-1}\left|H_{z} / H_{x}\right|$.

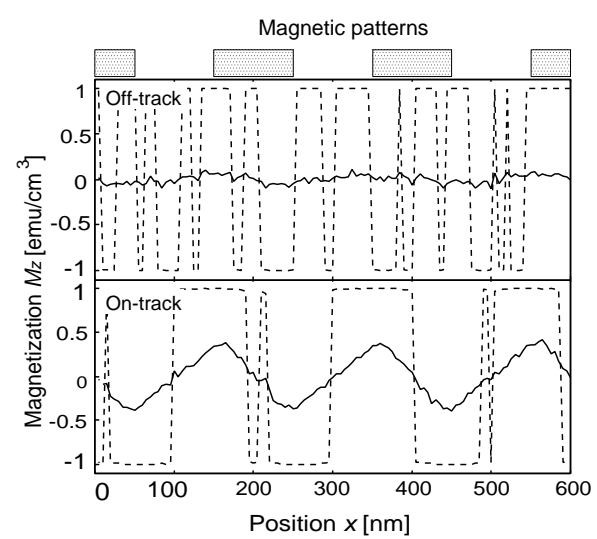

Fig. 4 Magnetization distribution along the on-track (lower) and off-track (upper) in EP. The solid line and dashed line indicate the magnetization distributions on the application of field and after duplication, respectively.

Fig. 5 に転写磁場 $H_{\mathrm{a}}$ を変化させてビット転写した記録層の 磁化分布を示す . Fig. 5 を見ると，マスター磁性膜凸部におい て対応する上向きの磁化が転写されていることがわかる . 転写 磁場が弱いときには , パターンエッジ部の磁化反転が起こり， 転写磁場の増加にともなって反転領域が単調に拡大することが 分かる.

Fig. 6 に転写磁場 4 kOe を印加しているときのトラック中心 部における記録磁場分布，及び，記録磁場が容易軸となす角 $\theta$ の分布を同樣に示す. Fig. 6 を見ると，磁性膜パターンのエッ ジ付近に容易軸となす角が大きな記録磁場か印加されているこ とがわかる . また, 弚のピーク位置は磁性膜パターンの外側に 位置している．この結果は，Fig. 5(b) に示したように，磁性膜 パターンエッジ部から磁化反転が起こること, 磁化分布が磁性 膜パターンに比べて拡がっていることとも対応している．

巨視的な磁気特性を用いた従来解析のように，記録磁場の膜 面垂直成分及び垂直方向ヒステリシスのみを元に解析した場 合, 磁化の面内方向成分が転写された磁化状態に及ぼす影響は
十分に議論出来なかった . 一方, 本研究のように, マイクロマ グネティックシミュレーション及び 3 次元の記録磁場分布を考 慮した場合，記録磁場の面内成分がビット形状に大きく関わつ ていることが分かる .

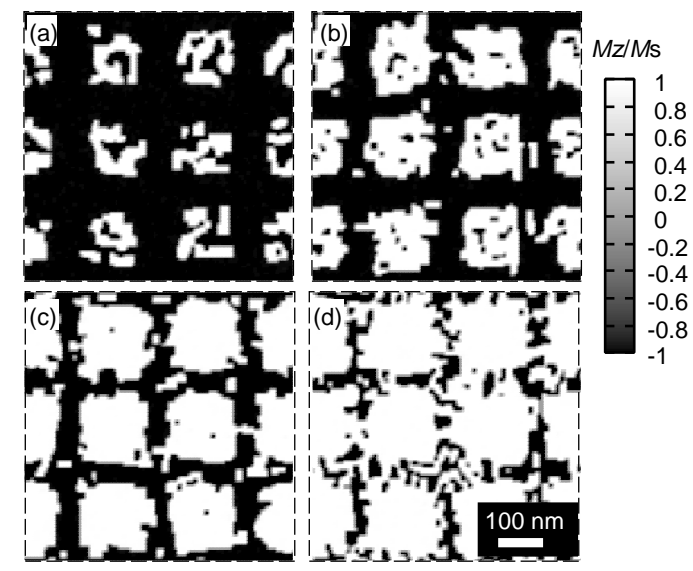

Fig. 5 Magnetization distributions for the recording layer duplicated by bit -printing with various duplication fields: (a) $2 \mathrm{kOe}$, (b) $4 \mathrm{kOe}$, (c) $6 \mathrm{kOe}$, and (d) $8 \mathrm{kOe}$.

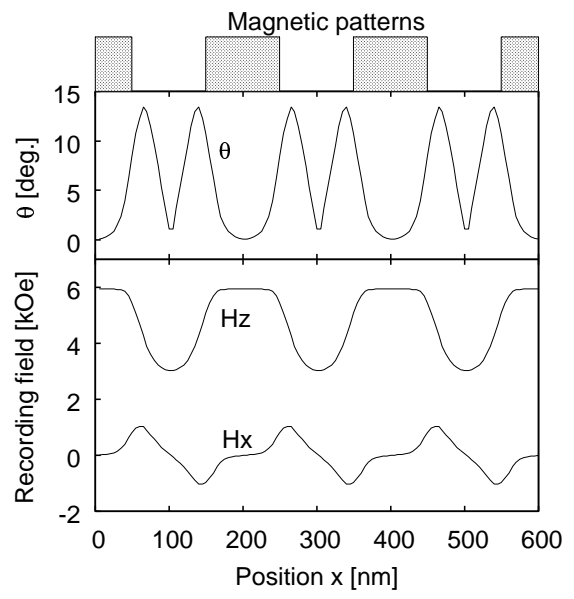

Fig. 6 Recording field distribution along the center of the track in BP (lower). The upper figure indicates angle $\theta$ with respect to the easy axis, which is defined as $\theta=\tan ^{-1}\left|H_{z} / H_{x}\right|$.

\section{2 再生出力の転写磁場依存性}

記録層からの洩れ磁場分布を用いて, オントラック時の再生 出力を計算した . 転写磁場を変えてエッジ転写された記録層の 再生波形を Fig. 7(a)に，ビット転写された記録層の再生波形 を Fig. 7(b) に示す.エッジ転写では, 磁場が弱いときに再生 波形にノイズが見られるものの, 転写磁場を強くすると矩形波 に近づくことが分かる．また，ビット転写では転写磁場 $2 \mathrm{kOe}$ のときにビット中心における再生波形の歪みが見られるもの の, 磁場が強くなるにしたがい, 再生波形が矩形波に近づくこ とが分かる．ただし，転写磁場が強くなるにつれて，磁化反転 領域が拡大することから，再生波形のビットシフトも増大する 傾向にある .

上述した再生波形の基本波振幅を計算し，基本波振幅の転 
写磁場依存性をまとめたものが Fig. 8 である .これを見ると， エッジ転写では磁場強度の増加にともなって転写特性が飽和す る.一方, ビット転写では保磁力付近に最適值が存在する。こ れらの傾向は以前のマクロな解析結果とも一致する.エッジ転 写の場合, $15 \mathrm{kOe}$ 程度の強い転写磁場を印加すると基本波振幅 がわずかに減少しているが, これは記録されるトラック幅が減 少して，所望のトラック幅に近づいているためである . ビット 転写の基本波振幅は, エッジ転写の兰れに比べて小さいが，こ れはビットシフトのために基本波が咸少したためであり，再生 波形全体の振幅に乥れほど大きな差はない，したがって，ビッ トシフトを考慮した最適パターン幅を選択することでビット転 写でも十分な転写特性を得ることが可能である。

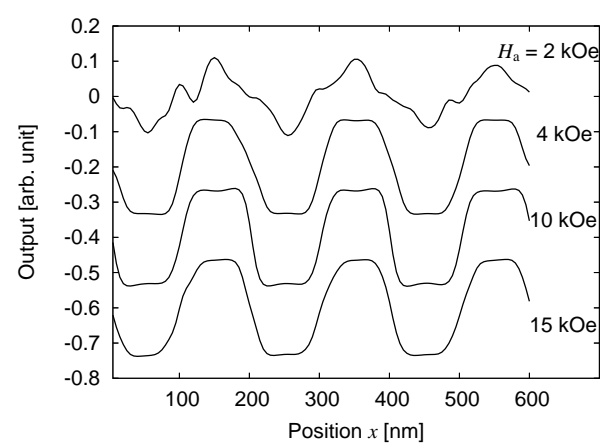

(a) Edge printing

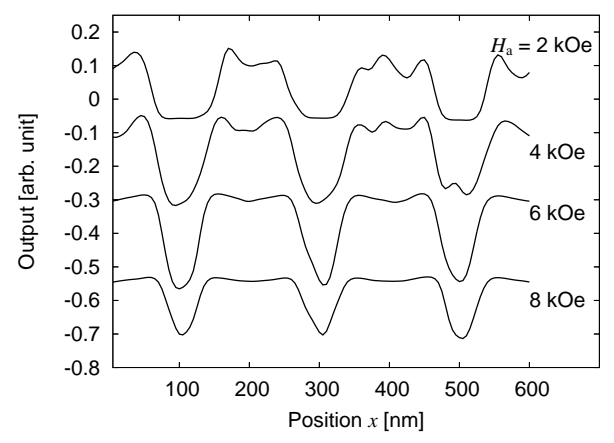

(b) Bit printing

Fig. 7 Output waveforms for (a) edge printing and (b) bit printing.

\section{3 粒子間交換結合が転写状態に及ぼす影響}

粒子間に働く交換結合が磁気転写に及ぼす影響について検討 した . 粒子間交換結合は保磁力付近の傾き $\alpha$ を主に変えるた め, 記録状態が大きく恋化することが予想される . 粒子間交換 結合 $A_{0}$ を基準值として, 交換結合を $A=0,2 A_{0}$ と変えて, エッジ転写及びビット転写したときの磁化状態を Fig. 9 に光 れ示す．エッジ転写では転写磁場 $15 \mathrm{kOe}$ ，ビット転写で は転写磁場 $4 \mathrm{kOe}$ のときの磁化状態を产れす．エッジ 転写においては, 粒子間交換結合を強くしてもほとんど磁化分 布には影響を与えないことが分かる.一方，ビット転写では磁 化分布が大きく変化する . 特に交換結合が大きいときには，パ ターン形状とよく整合した転写状態が得られており，交換結合 $A$ の増加はビット転写の転写特性を向上させることが分かる . また，ビット転写では交換結合 $A$ の増加とともに磁化反転領

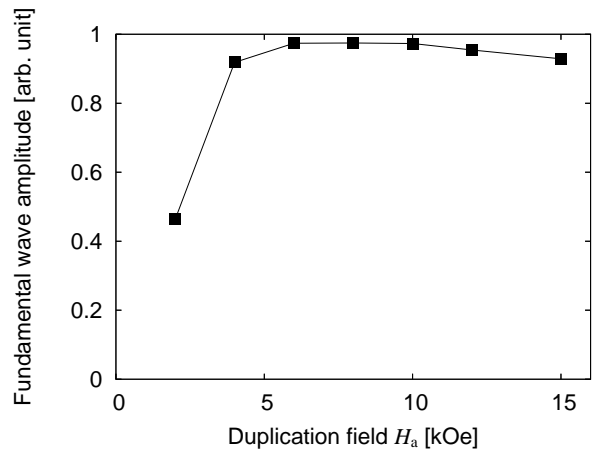

(a) Edge printing

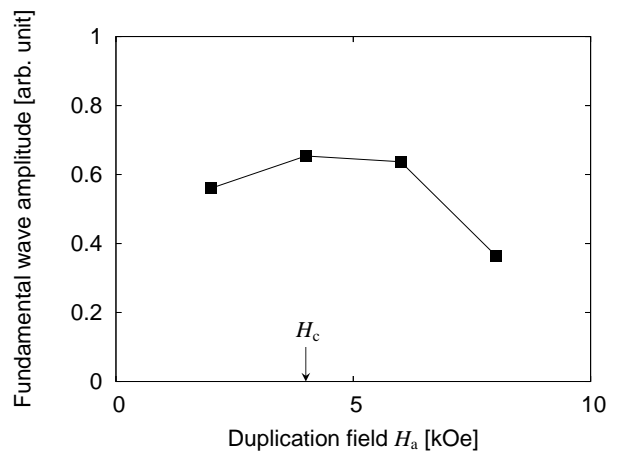

(b) Bit printing

Fig. 8 Dependence of duplication field on fundamental wave amplitude calculated from output waveforms for edge printing and bit printing.

域が拡大しており，垂直磁化膜に対応するパターン幅の設計が 必要であると示唆される .

粒子間交換結合の影響は, 各々の転写方法の初期状態に関係 する.エッジ転写では, 初期状態は AC 消磁状態であり, 磁化 過程は初磁化曲線に概ね従うため, 転写状態は保磁力付近の傾 きにほとんど依存しない, 一方, ビット転写では, 初期状態は DC 消磁状態であり，磁化過程は保磁力付近のメジャーループ に概ね従う．したがって, 保磁力付近の傾きが大きい垂直磁化 膜では, より明瞭にビット転写されると推定される .

粒子間交換結合に着目すると，エッジ転写では初期状態の磁 化はランダムに向いているため, 結果として粒子間交換結合 の影響は相殺する.したがって, 粒子間交換結合を変化させて も，転写状態に大きな変化は起こらないと考えられる．一方， ビット転写での初期磁化は一方向を向いているため, 粒子間交 換結合が最も強く働く状況である.しかし，ひとたび磁化反転 が起これば，交換結合の強さに対応した大きさのドメインがー 斉反転するため, 交換結合の増加とともに転写状態か改善した と理解することが出来る．

$$
4 \text { まとめ }
$$

本研究では, マイクロマグネティックシミュレーションを用 いて, 垂直磁気転写されたスレーブの磁化状態を計算し, 転写 条件及びスレーブの磁気特性か転写特性に及ぼす影響を考察し た .光の結果，以下のことが明らかとなった . 


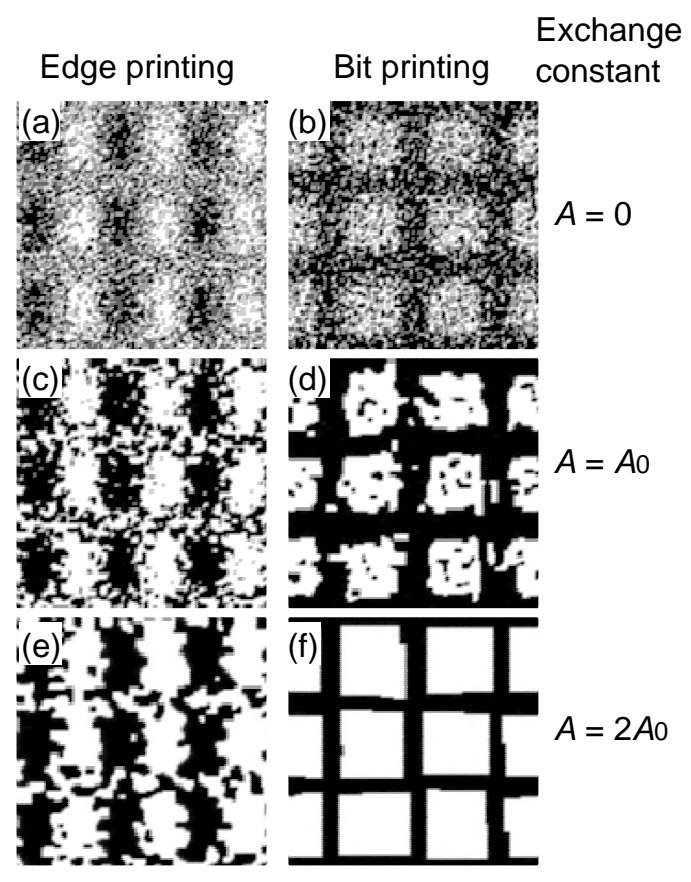

Fig. 9 Magnetization distributions for the recording layer with various exchange couplings in edge (left) and bit printing (right). The standard values, $A_{0}$, of exchange constant, $A$, is $1 \times 10^{-7}$ $\mathrm{erg} / \mathrm{cm}$.

（1）エッジ転写では, 転写磁場強度の増加にともなって, 才 フトラック領域の AC 消磁が促進される.
（2）ビット転写では，パターンエッジから磁化反転が起こ り, 転写磁場の増加にともなって反転領域が単調に増加 する .

(3) エッジ転写及びビット転写によって得られる再生出力の 転写磁場依存性はマクロな磁気特性を仮定した転写磁場 依存性と概ね一致した .

（4）粒子間交換結合が転写特性に及ぼす影響は，エッジ転写 では小さいが , ビット転写では大きい.ビット転写にお いては, 交換結合が大きいときに特に転写特性が向上す ることが期待できる .

謝辞 本研究の一部は, 新エネルギー・産業技術総合開発機構 (NEDO) 平成 18 年度産業技術研究助成事業, 及び日本学術振 興会科学研究費補助金 (C16560291) の支援により行われまし た . また , 長尾信氏を始めとする富士フイルム (株) の皆樣に は御協力，有益な御議論を頂きました．ここに深謝致します．

\section{References}

1) A. Saito, T. Hamada, T. Ishida, Y. Takano, and E. Yonezawa: IEEE Trans. Magn., 38, 2195 (2002)

2) M. Nishikawa, S. Wakamatsu, K. Ichikawa, T. Usa, M. Nagao, T. Ishioka, T. Yasunaga, T. Komine and R. Sugita: IEEE Trans. Magn. 42, 2612 (2006).

3) A. Izumi, Y. Nagahama, T. Komine, R. Sugita, and T. Muranoi: $J$. Magn. Soc. Jpn. , 30, 184 (2006)

4) T. Hamaguchi, T. Ichikawa, and H. Takano: J. Appl. Phys., 91, 8697 (2002).

2006 年 10 月 4 日受理, 2007 年 3 月 19 日採録 